\title{
内力増分を用いた浮動応力点積分の定式化による メッシュフリー大変形解析*
}

大西 有希 ${ }^{* 1}$, 天谷 賢治 $* 1$

\author{
Meshfree Large Deformation Analysis Based on Formulation \\ of Floating Stress-Point Integration with Incremental Internal Force
}

\author{
Yuki ONISHI*1 and Kenji AMAYA \\ ${ }^{* 1}$ Dept. of Mechanical and Environmental Infomatics, Tokyo Institute of Technology, \\ 2-12-1-W8-36, Ookayama, Meguro-ku, Tokyo 152-8552, Japan
}

\begin{abstract}
A modified formulation of floating stress-point integration with the updated Lagrangian procedure for large deformation analysis is presented. The modified formulation introduces an incremental internal force to the equilibrium equation instead of the virtual external force introduced in the previous formulation. With this modification, the temporal continuity of the mechanical equilibrium can be kept without introducing the virtual external force, and thus the accumulating error due to time advancing becomes small compared to our previous formulation. Several examples of large deformation analysis including large deformation patch tests are also presented to show the validity and accuracy of the proposing method in comparison with the finite element method.
\end{abstract}

Key Words : Galerkin Meshfree Method, Moving Least Squares, Stress-Point Integration, Large Deformation, Incremental Internal Force

\section{1. 緒言}

Galerkin 法に基づくメッシュフリー法は , 有限要素法 (FEM) の適用が困難な解析に対する有効な解析手段とし て実現が期待されている.FEMの適用が困難な解析の代表例として, 数百パーセントに及、゙歪みを含む大変形 問題が挙げられる.アダプティブメッシングは FEM の収束性を向上させる有効な手段であるが，弚の煩雑さと不 完全さ故に大变形解析で広く使われるまでには到っていない . 樹脂やガラス等のプレス成形 , ホットエンボス加 エ, 熱ナノインプリント等の大变形挙動の解析は産業上重要な課題であり, メッシュフリー大变形解析手法の確立 が待たれている.

Element-free Galerkin 法 $(\mathrm{EFGM})^{(1)} に$ 代表される古典的な Galerkin メッシュフリー法は，領域積分にバックグラ ウンドセルを必要とする.しかし大変形解析においてバックグラウンドセルを用いた積分を行う場合, 応力や歪 み等の状態量の輸送時に数值拡散が発生する為, 高精度な解析は困難である . この困難を避けるために提案され ている方法は大きく分けて2つあり (2)(3)，1つが節点積分，もう1つが応力点積分である.

節点積分 ${ }^{(4) \sim(8)}$ には幾つかの定式化が提唱されているが，ゼロエネルギーモードの発生を抑える為の安定化項を 加える必要があるという共通した欠点を持つ .これは有限要素法における低減積分要素がアワーグラスモードの 発生を抑える為に安定化項を要するという欠点と類似しており，根本的な解決は難しい，一方の応力点積分 ${ }^{(9) \sim(12)}$ ではゼロエネルギーモードが発生しない代わりに，応力点の生成と移動を行う必要がある．応力点積分による大 変形解析手法として , Li と Belytschko ${ }^{(9)}$ はボロノイ分割を併用した total Lagrange 法に基づく定式化を示している が, 検証計算では変形形状を有限要素法と定性的に比較するに留まっており, 未だ研究途上である.我々はバック グラウンドセルやボロノイ分割等を必要としない応力点積分として浮動応力点積分 ${ }^{(13)}$ を提案し, updated Lagrange

\footnotetext{
* 原稿受付 2011 年 2 月 16 日

*1 正員, 東京工業大学 情報環境学専攻（％ 152-8552 東京都目黑区大岡山 2-12-1-W8-36)

E-mail: yonishi@a.mei.titech.ac.jp
} 
法に基づく定式化を示すと共に幾つかの大変形解析例で有限要素法との定量的な比較を行って来た．しかし，従 来の定式化では釣合方程式の時間的連続性を満たす為に仮想外力を導入しており，乥れが故に節点荷重の誤差が 時間的に蓄積するという問題があった .

本研究では従来の浮動応力点積分の欠点であった仮想外力の使用を定式化から廃し，節点荷重誤差の時間的蓄 積を抑える新しい定式化を提案する . 提案する定式化では内力増分を用いた形式で釣合方程式を記述し，内力の 時間的連続性を満足させる. 本稿では提案手法の定式化の詳細について述べた後 , パッチテストを含む種 々の解 析例を FEM との比較と共に示し，提案手法の有効性を示す．

\section{2. 構 成 方 程 式}

本論文で扱う等方性弾性体の構成方程式は次式で表される．

$$
\boldsymbol{T}=\boldsymbol{C}: \boldsymbol{E} \quad(\text { i.e., } \stackrel{\circ}{\boldsymbol{T}}=C: D) .
$$

ただし, $\boldsymbol{T}$ は Chaucy 応力, $\boldsymbol{E}$ は Hencky 歪み, $\boldsymbol{T}$ は Chaucy 応力の Jaumann 速度, $\boldsymbol{D}$ はストレッチングテンソル である.また， $C$ は Lame の弾性定数 $(\lambda, \mu)$ と Kroneckerの $\delta$ を用いて次式で定義される4階の弾性係数テンソル である .

$$
C_{i j k l}=\lambda \delta_{i j} \delta_{k l}+2 \mu \delta_{i k} \delta_{j l}
$$

\section{3. 提案手法の定式化}

簡単の為 , 本稿では 2 次元平面歪みの準静的問題を対象とした定式化を示す . 提案手法においては仮想的な時間 発展を行うことによって準静的問題を解くこととし，本稿ではこれを単に時間発展と称する.変数の命名規則と して，応力点 $I$ にける物理量に対して左上添字 $I$ を，節点 $J$ における物理量に対して左下添字 $J$ を付する . ま た，増分後の時刻 $t+\Delta t$ における反復計算の試行值に対して右上添字 + を付する .

提案手法の処理の流れを示すフローチャートを図 1 にあらかじめ示しておく . 以降 , 本節では各処理の詳細を 述べる。

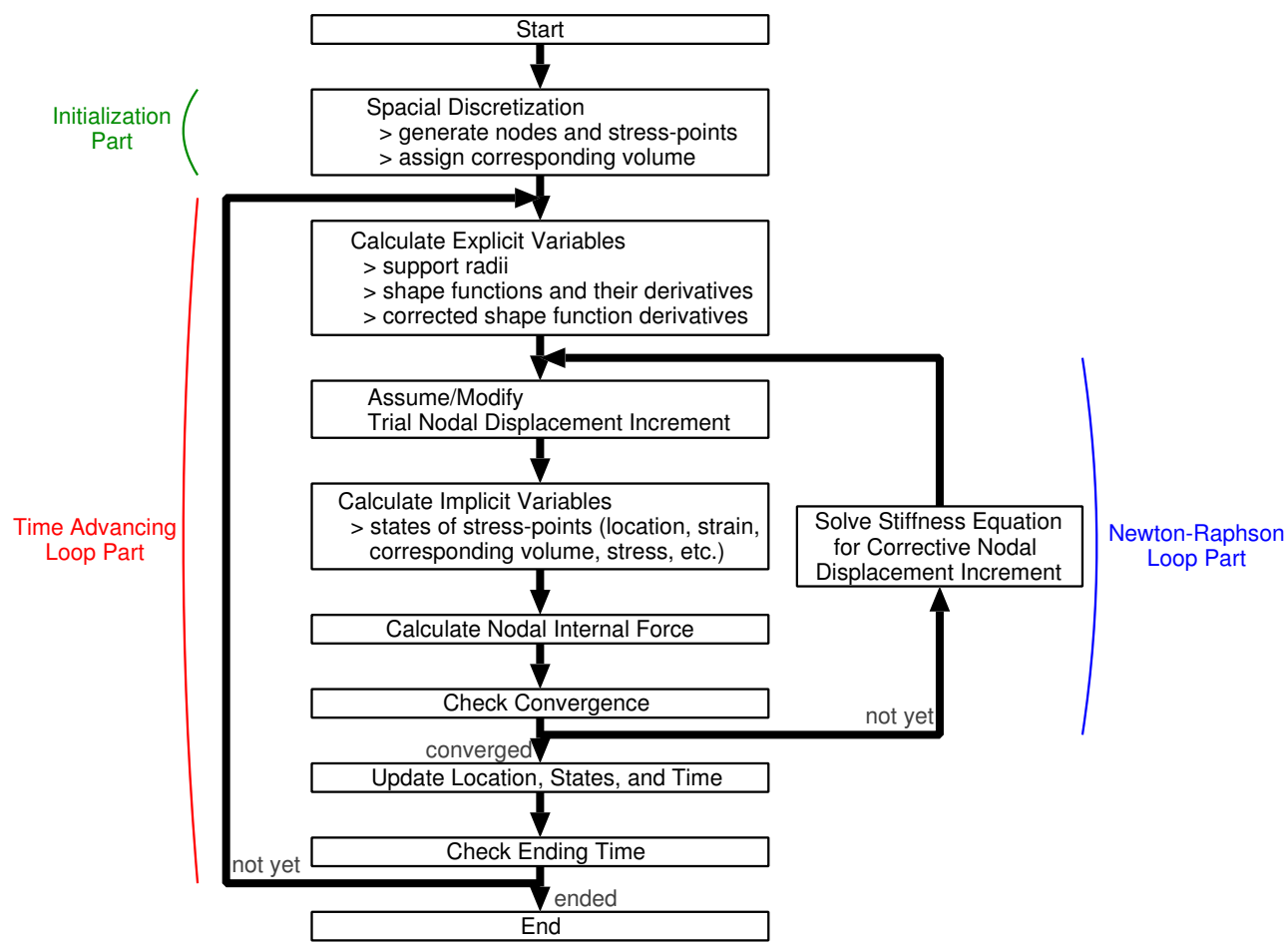

Fig. 1 Flowchart of the proposing meshfree method. The detail of each process is described in $\S 3$. 


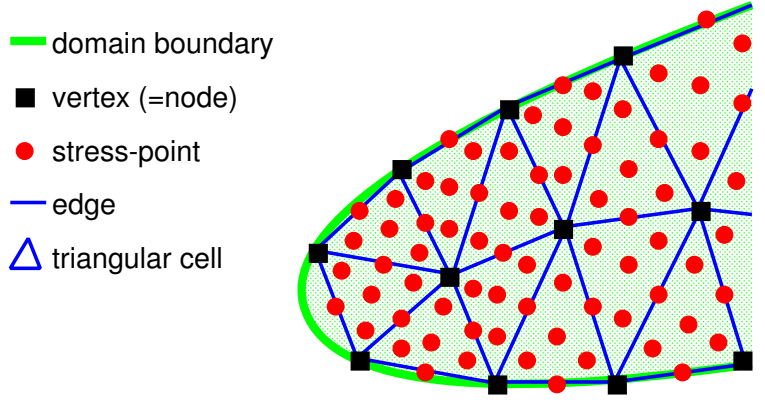

Fig. 2 Outline of spacial discretization of the present method in two-dimensional cases. The cells are used only at the initial state and are never referred during the time increments.

\section{$3 \cdot 1$ 空間離散化}

解析領域の初期形状に対して図 2 に示す樣な非構造格子による空間離散化を行う.ただし，この格子は初期形状 に対して生成する節点と応力点の初期化の為だけに用いられ，時間発展計算中には一切参照されないことに注意 されたい，有限要素法と同じ手順で節点とセルを生成した後，領域内に応力点を生成する．また，各応力点 $I に$ 対して担当体積 ${ }^{I} V^{\text {ini. }}$ を定める.

2 次元問題の場合, 解析領域は三角形セルにより分割し，応力点は各エッジの中央に 1 点づつと各三角形セル

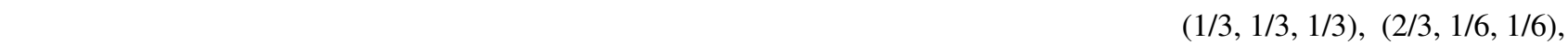
$(1 / 6,2 / 3,1 / 6),(1 / 6,1 / 6,2 / 3)$ の位置とする．また担当体積 ${ }^{I}{ }^{\text {ini. }}$ ( 2 次元解析の場合では実際には面積を意味する が，単位厚さを持つと考え，体積と称する) は次式で定める．

$$
{ }^{I} V^{\text {ini. }}=\left\{\begin{array}{ll}
\frac{1}{7} V_{I_{1}}+\frac{1}{7} V_{I_{2}} & \text { (for stress-points on edges) } \\
\frac{1}{7} V_{I} & \text { (for stress-points in cells) }
\end{array} .\right.
$$

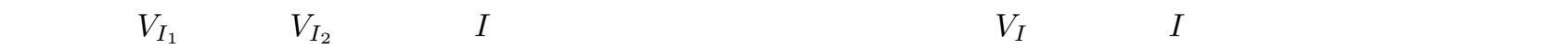

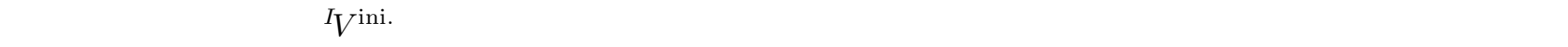
良好な解析結果が得られる生成法の一例であり，応力点の数や配置等の最適化は今後の課題である．

$3 \cdot 2$ 形状関数とその勾配

空間物理量の内挿には移動最小 2 乗近似 (MLS) ${ }^{(1)}$ を用いる .

まず，基底関数 $\{p(\boldsymbol{x})\}$ には次式で表される一次までの多項式を用いる．

$$
\{p(\boldsymbol{x})\}=\left\{1, x_{1}, x_{2}\right\} .
$$

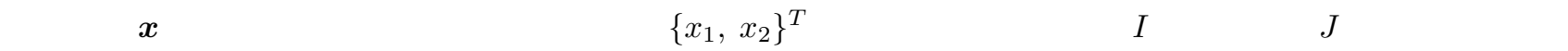

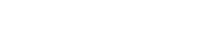

$$
\begin{gathered}
\left\{{ }^{I} p\right\}=\left\{p\left({ }^{I} \boldsymbol{x}\right)\right\}, \\
\left\{{ }_{J} p\right\}=\left\{p\left({ }_{J} \boldsymbol{x}\right)\right\},
\end{gathered}
$$

の樣に表すこととする．

次に, 2 点間の距離 $d$ に応じて定まる重み関数 $w(d)$ を

$$
w(d)= \begin{cases}\frac{1}{d}-1 & (0<d<1) \\ 0 & (1 \leq d)\end{cases}
$$

と定める . 以後, 応力点 $I$ における節点 $J$ の重みを

$$
{ }_{J}^{I} w=w\left(\frac{\left\|{ }_{J} \boldsymbol{x}-{ }^{I} \boldsymbol{x}\right\|}{{ }^{I} R}\right) .
$$


の樣に表すこととする．ただし， ${ }^{I} R$ はサポート半径であり，後述の通り時間と場所によって変化する值である． MLS により作成される応力点 $I$ における形状関数 $\left\{{ }^{I} N\right\}\left(=\left\{N\left({ }^{I} \boldsymbol{x}\right)\right\}\right)$ は，この基底関数と重み関数を用いて次 式で表される．

$$
\left\{{ }^{I} N\right\}=\left\{{ }^{I} p\right\}\left[{ }^{I} A\right]^{-1}\left[{ }^{I} B\right] .
$$

ただし,$\left[{ }^{I} A\right]$ および $\left[{ }^{I} B\right]$ は乥れ光れ次式で定義されるマトリックスである.

$$
\begin{aligned}
& {\left[{ }^{I} A\right]=\sum_{J \in I_{J}^{I J}}{ }_{J}^{I} w\left\{{ }_{J} p\right\}^{T}\left\{{ }_{J} p\right\},}
\end{aligned}
$$

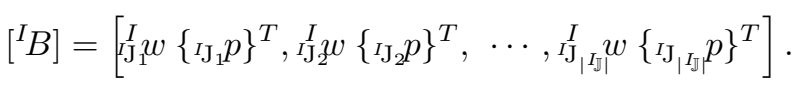

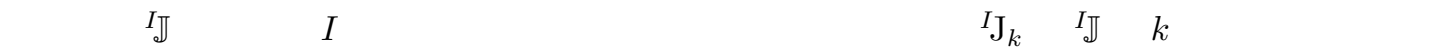

同樣に，応力点 $I$ における形状関数の ${ }^{I} x_{i}$ 方向の空間微分 $\left\{{ }^{I} N^{\prime}{ }_{i}\right\}\left(=\frac{\partial\left\{{ }^{I} N\right\}}{\partial x_{i}}\right)$ は次式で表される.

$$
\left\{{ }^{I} N^{\prime}{ }_{i}\right\}=\left(\frac{\partial\left\{{ }^{I} p\right\}}{\partial^{I} x_{i}}\right)\left[{ }^{I} A\right]^{-1}\left[{ }^{I} B\right]+\left\{{ }^{I} p\right\}\left(\frac{\partial\left[{ }^{I} A\right]^{-1}}{\partial^{I} x_{i}}\right)\left[{ }^{I} B\right]+\left\{{ }^{I} p\right\}\left[{ }^{I} A\right]^{-1}\left(\frac{\partial\left[{ }^{I} B\right]}{\partial^{I} x_{i}}\right) .
$$

ただし， $\frac{\left.\partial{ }^{I} A\right]^{-1}}{\partial^{I} x_{i}}$ は次式の通り計算されるマトリックスである.

$$
\frac{\partial\left[{ }^{I} A\right]^{-1}}{\partial^{I} x_{i}}=-\left[{ }^{I} A\right]^{-1}\left(\frac{\partial\left[{ }^{I} A\right]}{\partial^{I} x_{i}}\right)\left[{ }^{I} A\right]^{-1} .
$$

以後, 応力点 $I$ における節点 $J$ に対する形状関数の值を $J N$, 光の空間微分から成るベクトルを $J N^{\prime}$ と表すこと とする .

\section{$3 \cdot 3$ 積分補正}

本手法では形状関数の勾配に対してスケーリングによる補正 ${ }^{(18)}$ を施すことにより積分補正 (Integration Correction) を行う.すなわち，補正された形状関数の勾配 $J \widetilde{N^{\prime}}$ を

$$
{ }_{J}^{I} \widetilde{N^{\prime}}=\left(1+{ }^{I} \gamma\right){ }_{J}^{I} N^{\prime}
$$

と定義する．ただし， ${ }^{I} \gamma$ はに依らない補正係数である．

本定式化における divergence-free 条件 (integration constraint) ${ }^{(8)}$ (14) $^{(12}$ 次式で与えられる .

$$
\begin{array}{ll}
\sum_{I \in J \mathbb{I}}{ }_{J}^{I} \widetilde{\boldsymbol{N}}^{\prime} I=\mathbf{0} & \text { (for } J \text { in interior nodes), } \\
\sum_{I \in J \mathbb{I}}{ }_{J}^{I} \widetilde{\boldsymbol{N}}^{\prime}{ }^{I} V-{ }_{J} \boldsymbol{n}_{J} A=\mathbf{0} & \text { (for } J \text { in exterior nodes). }
\end{array}
$$

ただし,${ }_{J}^{\mathbb{I}}$ はサポート内に節点 $J$ を含む応力点の集合,${ }_{j} \boldsymbol{n}$ は表面節点 $J$ の外向き単位法線ベクトル,${ }_{J} A$ は節点 $J$ の担当表面積 ( 2 次元解析では輪郭線長) を表す.式(15) および (16)に式 (14) を代入し， ${ }^{\prime} \gamma$ を知数とする連 立方程式にまとめると次式を得る .

$$
\left[\mathcal{N}^{\prime}\right]\{\gamma\}=\{\mathcal{R}\} .
$$

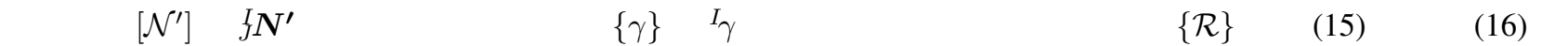
残差からなる右辺べクトルである. 本手法では応力点の数が節点の数を上回る為, 式 (17) は劣決定系となる. 光 こで本稿では, 許される範囲で補正量を最も小さく抑える為, 式(17)の最小ノルム解を $\{\gamma\}$ として用いた .

なお，本手法では形状関数の作成にMLS を用いていること，および形状関数の勾配の補正にスケーリングを用 いていることから，次式で表される Partition of Unity は自動的に満たされている．

$$
\sum_{J \in I J}^{I J} I_{J}^{I} N=1 \quad \text { and } \quad \sum_{J \in I J}^{I} \widetilde{N^{\prime}} \widetilde{N^{\prime}}=\mathbf{0} .
$$

ただし，IIは応力点 $I$ のサポート領域内に存在する節点の集合を表す . 


\section{4 準陰的時間発展スキーム}

提案手法は大歪みを含む大変形問題に主眼を置いている為, 各応力点におけるサポートを初期状態で決定して 一定とはせず，変形状態に合わせてこれを更新する updated Lagrange 法を採る .

完全な陰的時間発展を行う場合，各応力点におけるサポート，および光れに伴って変化する重みや形状関数等の 更新は後退差分による収束計算 (Newton-Raphson ループ) 内で行う必要がある .しかしこの完全な陰的時間発展 を適用すると，強い非線形性の為に Newton-Raphson 法の収束性が著しく悪化する．光こで提案手法では，全ての 変数を Newton-Raphson ループ内で更新を行う陰的変数とはせず, 一部の変数は時間ステップの開始時にのみ更新 を行う陽的変数とし, 収束性を確保する.すなわち, 提案する時間発展スキームは一貫して後退差分を用いる後退 Euler 法 (fully-implicit) と前進 Euler 法 (explicit)の中間的な手法であり，流体解析や流体構造連成解析の分野で一

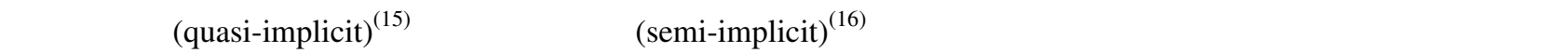

\subsection{1 陽的変数}

サポート半径, 重み, 形状関数と光の勾配は陽的変数として取り扱う. 各応力点 $I$ におけるサポート半径 ${ }^{I} R$ は, 次の $2 つ$ つ条件を満足する最小の値とする .

・サポートに含まれる節点数 $(|I| I \mid)$ が 6 以上

・式 (10)で定義されるマトリックス $\left[{ }^{I} A\right]$ の条件数 $\left(\operatorname{cond}\left(\left[{ }^{I} A\right]\right)\right)$ が $10^{5}$ 以下

具体的実装においては，充分小さな值を ${ }^{I} R$ の初期值とし，兴れに 1.01 を乗じて $\operatorname{cond}\left(\left[{ }^{I} A\right]\right)$ を計算する操作を繰り 返し行い, $\operatorname{cond}\left(\left[{ }^{I} A\right]\right)$ が $10^{5}$ を初めて下回った時点の ${ }^{I} R$ をサポート半径と定めた .これにより，表面近傍および 大変形の影響等で節点分布が不均質となる状況下であっても，形状関数の計算が破綻を来たすことを避けること が出来る.重み , 形状関数と光の勾配の計算方法は $33 \cdot 2$ に示した通りである .

\subsection{2 陰的変数}

上記の陽的変数以外の状態量は全て陰的変数として取り扱う. 応力点 $I$ の試行位置 ${ }^{I} \boldsymbol{x}^{+}$は, 形状関数およびサ ポート領域内に存在する節点群の変位を用いて次式の通り更新する .

$$
{ }^{I} \boldsymbol{x}^{+}={ }^{I} \boldsymbol{x}+\sum_{J \in I_{I}}{ }_{J}^{I} N\left({ }_{J} \boldsymbol{x}^{+}-{ }_{J} \boldsymbol{x}\right) .
$$

ただし,${ }_{J} \boldsymbol{x}^{+}$は節点 $J$ の試行位置ベクトルである . 応力点 $I$ の試行担当体積 ${ }^{I} V^{+}$は次式で更新する.

$$
{ }^{I} V^{+}={ }^{I} V^{\text {ini. }} \operatorname{det}\left({ }^{I} \boldsymbol{F}^{+}\right) .
$$

ただし,${ }^{I} \boldsymbol{F}$ は変形勾配テンソルを表す .なお , 変形勾配テンソル ${ }^{I} \boldsymbol{F}$ や速度勾配テンソル ${ }^{I} \boldsymbol{L}$ などの変形状態を表 す変数の計算方法は一般的な有限要素法 ${ }^{(17)}$ と同じであるため，ここでは記載を省略する .

\section{5 釣合方程式}

解くべき釣合方程式は, 次式で表される試行節点内力ベクトル $\left\{f^{\text {int.+ }}\right\}$ と試行節点外力ベクトル $\left\{f^{\text {ext.+ }}\right\}$ 間の釣 合式である .

$$
\left\{f^{\text {ext. }+}\right\}-\left\{f^{\text {int. }}\right\}=\{0\} .
$$

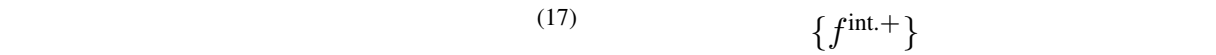

$$
\left\{f^{\text {int. }}\right\}=\sum_{I \in \mathbb{I}_{\Omega}} \int_{I_{\Omega}}\left[\widetilde{B}_{\mathrm{L}}\right]^{T}\left\{T^{+}\right\} \mathrm{d} \Omega \simeq \sum_{I \in \mathbb{I}_{\Omega}}\left[{ }^{I} \widetilde{B}_{\mathrm{L}}\right]^{T}\left\{{ }^{I} T^{+}\right\} V^{I} .
$$

ただし， $\mathbb{I}_{\Omega}$ は解析領域内の全応力点の集合， $I_{\Omega}$ は応力点 $I$ の担当領域， $\left[{ }^{I} \widetilde{B}_{\mathrm{L}}\right]$ は次式で表されるマトリクスである

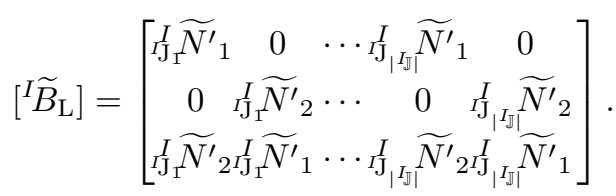


しかし , 浮動応力点積分では updated Lagrange 法によりサポート領域が時間ステップ毎に更新される為 , $\left[{ }^{I} \widetilde{B}_{\mathrm{L}}\right]$ も 時間ステップ毎に不連続に更新される . 従って式 (22)を $\left\{f^{\mathrm{int} .+}\right\}$ の定義として採用すると，節点内力ベクトルの 時間的連続性が保たれなくなり，収束性が悪化するばかりか解析精度も悪化する. 乥こで, 本研究では次に示す 増分形式の仮想仕事式に基づき釣合方程式の定式化を行う．

増分形仮想仕事式の一形式は次式 ${ }^{(20)}$ で与えられる

$$
\int_{v} \dot{\boldsymbol{\Pi}}_{t}^{T}(t): \delta \boldsymbol{F}_{t}(t) \mathrm{d} v=\int_{s} \dot{\underline{t}}_{t}(t) \cdot \delta \boldsymbol{u} \mathrm{d} s+\int_{v} \rho \dot{\boldsymbol{g}} \cdot \delta \boldsymbol{u} \mathrm{d} v .
$$

ただし,$v$ は現配置の体積， $s$ は現配置の境界,$\cdot 」 は$ は物質時間微分， $\Pi_{t}(t)$ は現配置を基準配置とする第1 PiolaKirchhoff 応カテンソル, $\delta \boldsymbol{F}_{t}(t)$ は現配置を基準配置とする変形勾配テンソルの変分， $\underline{t}_{t}(t)$ は現配置を基準配置と する表面力ベクトル,$\delta \boldsymbol{u}$ は变位ベクトルの変分,$\rho$ は密度, $\boldsymbol{g}$ は体積力加速度ベクトルである

ここで , 時間増分計算中の物質時間微分を線形近似することにより， $\dot{\Pi}_{t}^{T}(t)$ および $\underline{\dot{t}}_{t}(t)$ は光れ光れ $\Delta \Pi_{t}^{T+} / \Delta t$ および $\Delta \underline{\boldsymbol{t}}_{t} / \Delta t$ と近似出来る．さらに，Galerkin 法を用いて空間離散化することにより，応力点における $\delta \boldsymbol{u}$ およ

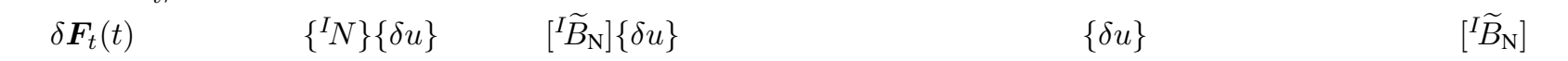
次式で表されるマトリクスを表す。

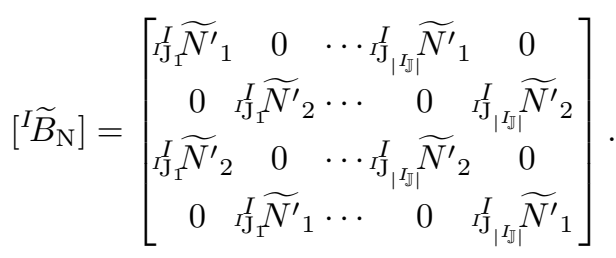

以上の近似により，離散化された増分形釣合方程式が次の樣に得られる .

$$
\left\{\Delta f^{\text {ext. }}\right\}-\left\{\Delta f^{\text {int. }}\right\}=\{0\} .
$$

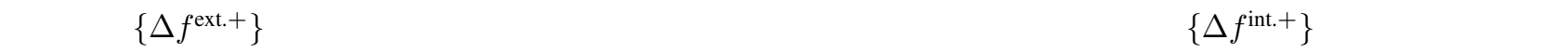
分べクトルであり，次式で表される．

$$
\left\{\Delta f^{\text {int. }}\right\}=\sum_{I \in \mathbb{I}_{\Omega}} \int_{I_{\Omega}}\left[\widetilde{B}_{\mathrm{N}}\right]^{T}\left\{\Delta \Pi_{t}^{T+}\right\} \mathrm{d} \Omega \simeq \sum_{I \in \mathbb{I}_{\Omega}}\left[{ }^{I} \widetilde{B}_{\mathrm{N}}\right]^{T}\left\{\Delta^{I} \Pi_{t}^{T+}\right\}^{I} V^{+} .
$$

ここで, $\left\{\Delta^{I} \Pi_{t}^{T+}\right\}$ は $\Delta^{I} \Pi_{t}^{T+}$ の列べクトル表記であり，定義に従って次式 ${ }^{(20)}$ の通り計算される.

$$
\Delta^{I} \boldsymbol{\Pi}_{t}^{T+}=\Delta^{I} \boldsymbol{T}^{+}+\operatorname{tr}\left({ }^{I} \boldsymbol{L}^{+}\right)^{I} \boldsymbol{T} \Delta t-{ }^{I} \boldsymbol{T}^{I} \boldsymbol{L}^{T+} \Delta t .
$$

ただし， $\boldsymbol{L}$ は速度勾配テンソルを表す . 実際の実装においては，釣合方程式の残差が時間増分毎に蓄積してしま うことを防ぐ為，式 (26)の各項を時間積算して得られる

$$
\left(\left\{f^{\text {ext. }}\right\}+\left\{\Delta f^{\text {ext. }}\right\}\right)-\left(\left\{f^{\text {int. }}\right\}+\left\{\Delta f^{\text {int. }}\right\}\right)=\{0\}
$$

を解くべき釣合方程式とする．すなわち，これは式(21)の $\left\{f^{\mathrm{int} .+}\right\}$ を式 (22)ではなく次の式 (30)により定義した ことに等しい．

$$
\left\{f^{\text {int. }}\right\}=\left\{f^{\text {int. }}\right\}+\sum_{I \in \mathbb{I}_{\Omega}}\left[{ }^{I} \widetilde{B}_{\mathrm{N}}\right]^{T}\left\{\Delta^{I} \Pi_{t}^{T+}\right\}{ }^{I} V^{+} .
$$

式(28)より， $\Delta t \rightarrow+0$ の極限において $\Delta^{I} \boldsymbol{\Pi}_{t}^{T+} \rightarrow \mathbf{0}$ がサポート領域の更新の有無に関わらず成立することが分 かる.すなわち，式(30)で計算される $\left\{\Delta f^{\text {int.+ }}\right\}$ は， $\Delta t \rightarrow+0$ の極限において常に $\left\{\Delta f^{\text {int.+ }}\right\} \rightarrow\{0\}$ となる . 従つ て , 式 (29) を解くべき釣合方程式とすることにより節点内力ベクトルの時間的連続性が確実に保たれる .

式 (29) および (30)の導出についての以上の議論は , 数学的に充分に繳密であるとは言えない . 本稿ではこれら の式の正当性を後述の解析例によって示すこととし，これらの式の数学的に厳密な導出については今後の課題と したい. 
3.6 剛性方程式

接線岡性マトリックスの近似 $[K]$ は次式の通り定義する.

$$
\begin{aligned}
{[K] } & =\sum_{I \in \mathbb{I}_{\Omega}} \int_{I_{\Omega}}\left(\left[{ }^{I} \widetilde{B}_{\mathrm{L}}\right]^{T}\left[{ }^{I} C_{\mathrm{L}}^{+}\right]\left[{ }^{I} B_{\mathrm{L}}\right]+\left[{ }^{I} \widetilde{B}_{\mathrm{N}}\right]^{T}\left[{ }^{I} C_{\mathrm{N}}^{+}\right]\left[{ }^{I} B_{\mathrm{N}}\right]\right) \mathrm{d} \Omega \\
& \simeq \sum_{I \in \mathbb{I}_{\Omega}}\left(\left[{ }^{I} \widetilde{B}_{\mathrm{L}}\right]^{T}\left[{ }^{I} C_{\mathrm{L}}^{+}\right]\left[{ }^{I} B_{\mathrm{L}}\right]+\left[{ }^{I} \widetilde{B}_{\mathrm{N}}\right]^{T}\left[{ }^{I} C_{\mathrm{N}}^{+}\right]\left[{ }^{I} B_{\mathrm{N}}\right]\right){ }^{I} V,
\end{aligned}
$$

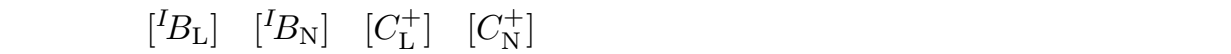

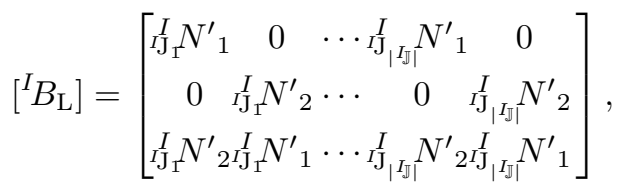

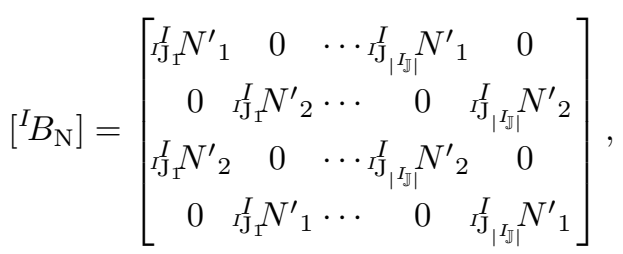

$$
\begin{aligned}
& {\left[{ }^{I} C_{\mathrm{L}}^{+}\right]=[C]-\left[{ }^{I} \mathcal{C}^{+}\right]} \\
& =\left[\begin{array}{ccc}
\lambda+2 \mu & & \text { sym. } \\
\lambda & \lambda+2 \mu & \\
0 & 0 & \mu
\end{array}\right]-\left[\begin{array}{ccc}
{ }^{I} T_{11}^{+} & -{ }^{I} T_{11}^{+} & { }^{I} T_{12}^{+} \\
-{ }^{I} T_{22}^{+} & { }^{I} T_{22}^{+} & { }^{I} T_{12}^{+} \\
0 & 0 & \frac{{ }^{I} T_{11}^{+}+{ }^{+} T_{22}^{+}}{2}
\end{array}\right], \\
& {\left[{ }^{I} C_{\mathrm{N}}^{+}\right]=\left[\begin{array}{cccc}
{ }^{I} T_{11}^{+} & & & \text {sym. } \\
0 & { }^{I} T_{22}^{+} & & \\
{ }^{I} T_{12}^{+} & 0 & { }^{I} T_{22}^{+} & \\
0 & { }^{I} T_{12}^{+} & 0 & { }^{I} T_{11}^{+}
\end{array}\right] .}
\end{aligned}
$$

釣合方程式を満たすようにする為の修正節点変位増分ベクトル $\{\delta u\}$ は, 次の近似剛性方程式を解くことにより 求める.

$$
\left[K^{+}\right]\{\delta u\}=\left\{f^{\text {ext.+ }}\right\}-\left\{f^{\text {int. }}\right\} .
$$

得られた $\{\delta u\}$ を用いて，試行節点変位増分ベクトルを

$$
\left\{\Delta u^{+}\right\} \longleftarrow\left\{\Delta u^{+}\right\}+\{\delta u\}
$$

により更新する . Newton-Raphson 法により釣合方程式の残差 ，すなわち式 (36) の右辺のノルムが充分に小さくな るまでこれを繰り返す．

なお，ディリクレ境界条件は FEMで一般的用いられる方法，すなわち $[K]$ の該当行を対角成分を除いてゼロと する方法 ${ }^{(17)}$ を用いた .これは EFGM で用いられる幾つかの方法 ${ }^{(2)(3)}$ と異なり，節点座標は正確にディリクレ境界 条件を満たすものの局所近似される変位空間はディリクレ境界条件を正確には満たさない，しかし，本研究で用 いるサポート領域は充分に小さい為，この事による精度低下は軽微である ${ }^{(8)}$. 


\section{4. 解 析 例}

$4 \cdot 1$ 大変形パッチテスト その1

解析領域を $1 \mathrm{~m} \times 1 \mathrm{~m}$ の矩形領域とし, 輪郭線上にある全ての節点に最終強制変位

$$
\boldsymbol{u}(\boldsymbol{x})=\left\{0.1+0.2 x_{1}-0.1 x_{2}, 0.2-0.1 x_{1}+0.2 x_{2}\right\}^{T}
$$

を与える．節点数が 36 , 初期化用セル数が 50 ，応力点数が 285 であり，図 3 の通り解析領域に均等に配置した 解析に用いた弾性物性値は， $\lambda=0.576923 \mathrm{GPa}$ および $\mu=0.384615 \mathrm{GPa}$ (ヤング率 $1 \mathrm{GPa}$, ポアン比 0.3 に相当) である.強制変位がゼロから線形的に増加するとした仮想的な時間発展を行い, 均等な 100 ステップに時間分割し た.ABAQUS/Standard ${ }^{(19)}$ で図 3 の初期化用セルと同一の3 節点三角形1 次要素分割を用い, 均一な 1,000 ステッ プに時間分割して得られた解 (参照解) も別途用意した .

最終状態の変形図, および Mises 応力分布を図 4 左側に示す. 同じく最終状態での参照解の変形図, および Mises 応力分布を図 4 右側に併せて示す . 提案手法の Mises 応力は $177.2 \mathrm{MPa}$ で領域内一定 , 参照解の Mises 応力は 176.9

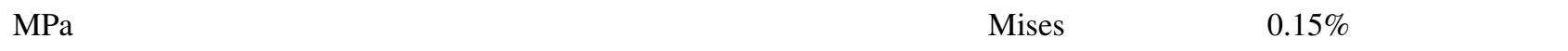
法は大変形問題に対して充分な精度でパッチテストを通過していると言える .

$4 \cdot 2$ 大変形パッチテスト その2

先述の大変形パッチテスト谷の1 と同じ解析領域, 同じ空間離散化, 同じ弾性物性値とし, 輪郭線上にある全 ての節点に最終強制変位

$$
\boldsymbol{u}(\boldsymbol{x})=\left\{3 x_{1},-0.75 x_{2}\right\}^{T}
$$

を与える . 強制変位がゼロから線形的に増加するとした仮想的な時間発展を行い，均等な 200 ステップに時間分 割した。

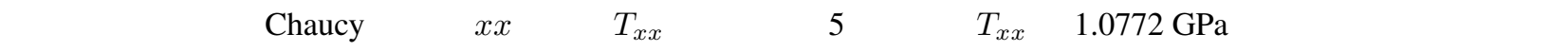

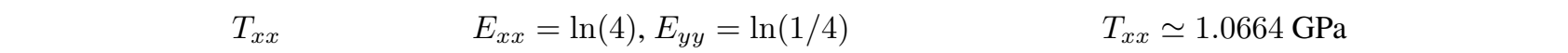

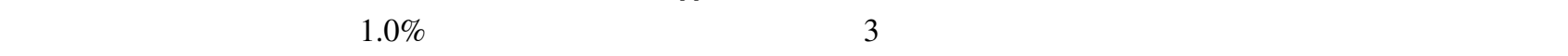
パッチテストを通過していると言える．

\section{$4 \cdot 3$ 片持ち梁の曲げ解析}

解析領域を $1 \mathrm{~m} \times 0.1 \mathrm{~m}$ の矩形領域とし，左辺を完全拘束，右上角に下向きの $400 \mathrm{kN}$ の集中死荷重を加える.節 点数が 335 , 初期化用セル数が 558 , 応力点数が 3,124 であり，図 6 の通り解析領域に均等に配置した . 解析に用 いた弾性物性值は， $\lambda=0.576923 \mathrm{GPa}$ および $\mu=0.384615 \mathrm{GPa}$ (ヤング率 $1 \mathrm{GPa}$ ，ポアソン比 0.3 に相当 ）である. 死荷重がゼロから $400 \mathrm{kN}$ へと線形的に増加するとした仮想的な時間発展を行い, 自動時間増分により不均一な約 200 ステップに時間分割した . ABAQUS/Standard の 8 節点四角形 2 次要素を $10 \times 100$ の 1,000 要素用い，均一な 1,000 ステップに時間分割して得られた解 (参照解) も別途用意した .

最終状態の変形図, および Mises 応力分布を図 7 左側に示す. 同じく最終状態での参照解の変形図, および Mises 応力分布を図 7 右側に併せて示す. 変形の樣子, Mises 応力分布共に互いに良く一致していることが分かる.

仮想的な時間発展中の荷重点における鉛直変位の時刻歴を図 8 に示す. 荷重点における最終鉛直変位は提案手

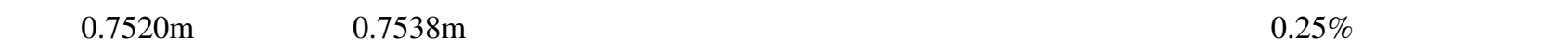
法は大たわみ問題に対して充分な精度を有していると言える．

また, 本解析例で与える死荷重を $1 \mathrm{kN}$ とした微小変形域の問題において，荷重点における鉛直変位誤差と節点 数との関係をグラフにしたものを図 9 に示す.グラフの傾きから，提案手法は節点数の増加に対して 1 次収束で あることが分かる . これは提案手法が MLS の基底関数の次数を 1 次までとしていることと符合している . 


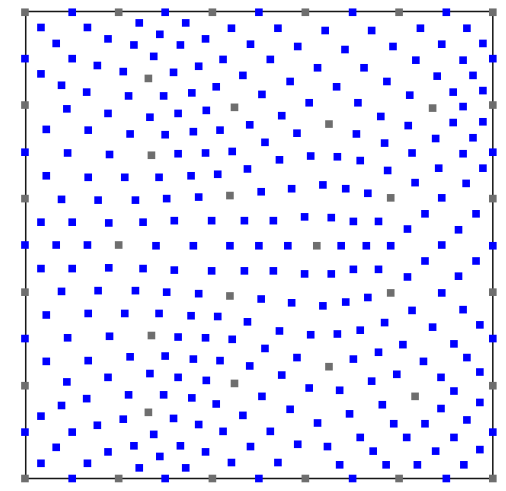

Fig. 3 Initial locations of nodes (gray dots) and stress-points (blue dots) for the patch tests.
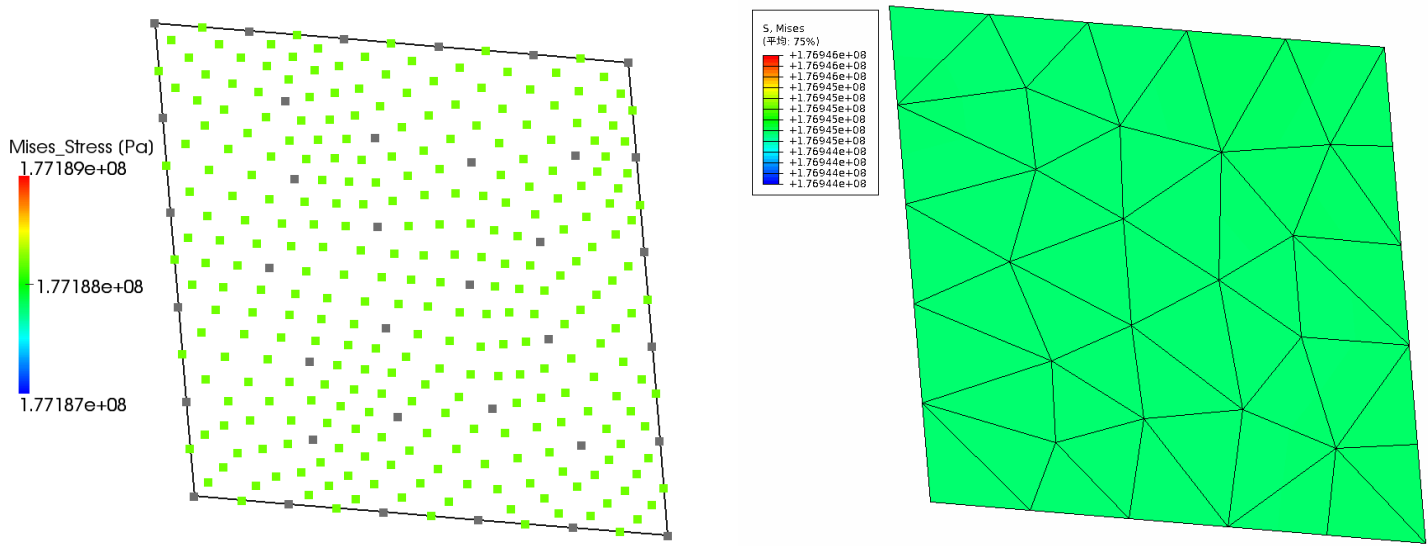

Fig. 4 Deformed shape and Mises stress distribution in the final state of the patch test no. 1 with the proposing method (on the left) and ABAQUS/Standard (on the right). The magnitude of Mises stress is about 177.2 MPa and 176.9 MPa, respectively.
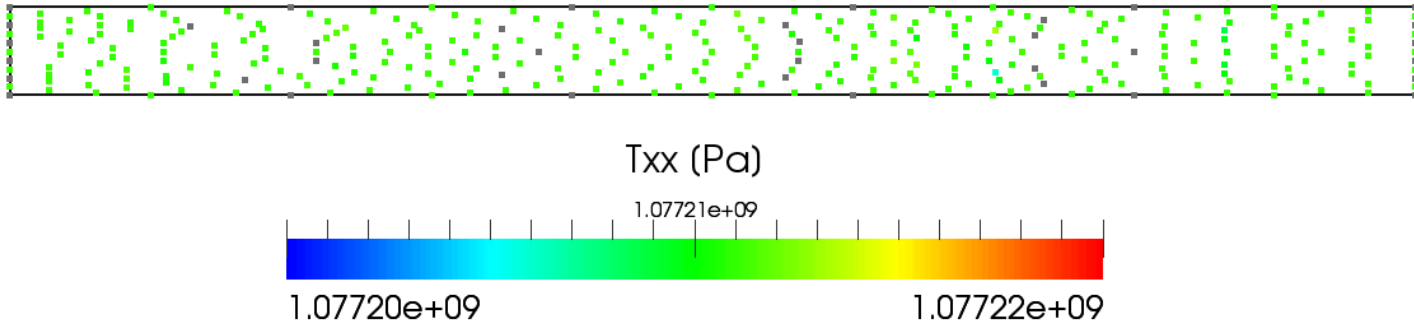

Fig. 5 Deformed shape and $T_{x x}$ distribution in the final state of the patch test no. 2 with the proposing method. The calculated $T_{x x}$ of the proposing method is about $1.0772 \mathrm{GPa}$, while that of analytical solution is about $1.0664 \mathrm{GPa}$. 


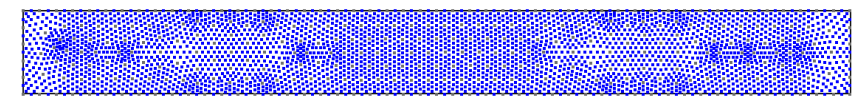

Fig. 6 Initial locations of nodes (gray dots) and stress-points (blue dots) for the cantilever example.
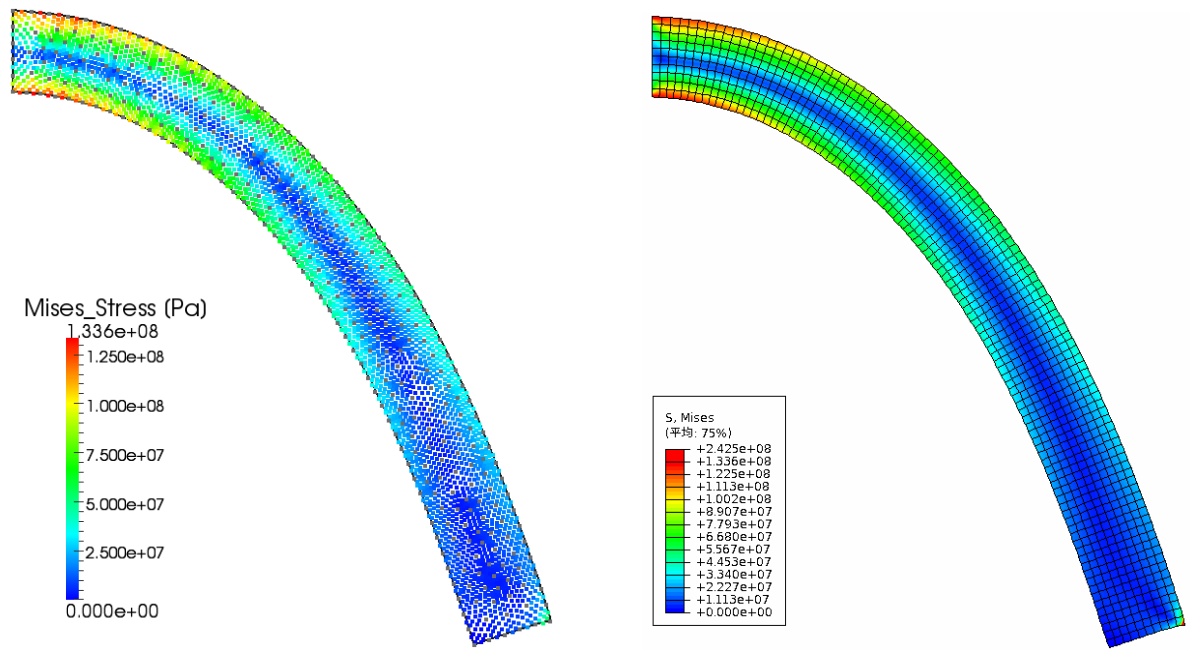

Fig. 7 Deformed shape and Mises stress distribution in the final state of the cantilever example with the proposing method (on the left) and ABAQUS/Standard (on the right).

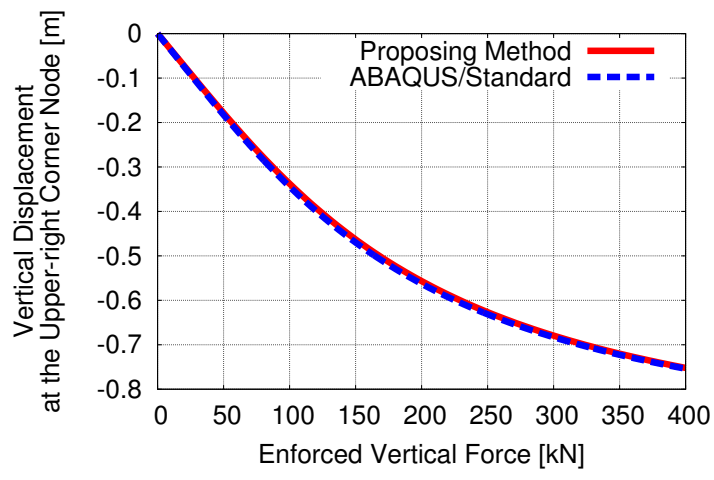

Fig. 8 Comparison of vertical displacement at the loading point (upper-right corner node) of the cantilever example between the proposing method and ABAQUS/Standard.

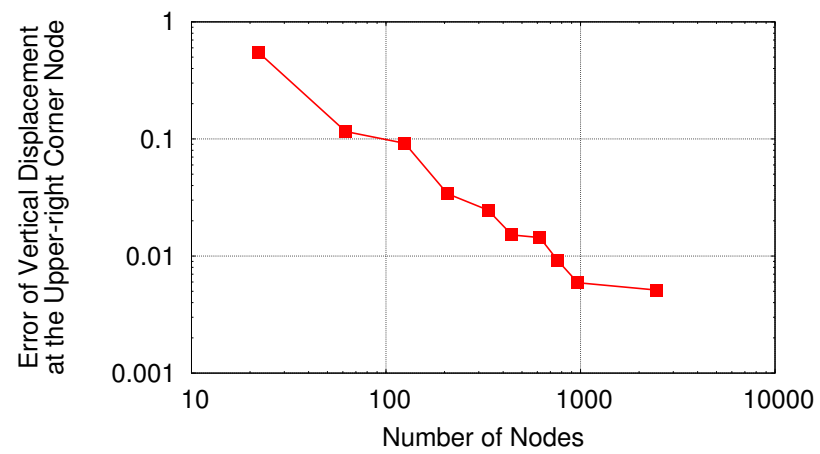

Fig. 9 Relationship between the number of nodes and the error of vertical displacement at the loading point (upper-right corner node) of the cantilever example with $1 \mathrm{kN}$ loading. The gradient of this figure shows the rate of convergence of the proposing method is linear. 


\section{$4 \cdot 4$ 一軸引張解析}

解析領域を $1 \mathrm{~m} \times 1 \mathrm{~m}$ の矩形領域に半径 $0.8 \mathrm{~m}$ の $1 / 4$ 円の穴が空いている領域とし，左辺を左右拘束，下辺を上下 拘束し，上辺を左右拘束と同時に上方向に $1 \mathrm{~m}$ 強制変位させる.節点数が 873 , 初期化用セル数が 1,598 , 応力点数 が 8,862 であり，図 10 の通り解析領域に均等に配置した . 解析に用いた弾性物性值は， $\lambda=0.576923 \mathrm{GPa}$ おび $\mu=0.384615 \mathrm{GPa}$ (ヤング率 $1 \mathrm{GPa}$ ，ポアソン比 0.3 に相当 ) である.強制変位がゼロから線形的に増加するとした 仮想的な時間発展を行い，自動時間増分により時間発展は不均一な約 250 ステップに分割した . ABAQUS/Standard で図 10 の初期化用セルと同一の 3 節点三角形 1 次要素分割を用い, 自動時間増分による適当な時間発展を行って 得られた解 (参照解) も別途用意した。

$0.5 \mathrm{~m}$ 強制変位させた時点での提案手法の変形図 , および Mises 応力分布を図 11 左側に示す . 同じく $0.5 \mathrm{~m}$ 強制 変位させた時点での参照解の変形図 , および Mises 応力分布を図 11 右側に示す. 変形図は互いに良く一致してお り，Mises 応力分布も全域に渡り良く一致している。

$1 \mathrm{~m}$ 強制変位させた最終状態での提案手法の变形図，および Mises 応力分布を図 12 に示す. 参照解は強制変位 が $0.5 \mathrm{~m}$ を少し越えた時点で計算が続行不能に陥った為，提案手法の結果のみ示している.メッシュを用いる手法 では解が得られない大変形解析に対し，提案手法で妥当な変形状態および応力状態が得られていることが分かる 仮想的な時間発展中の図中右下角の節点における水平变位の時刻歴を図 13 に示す. 参照解の計算が続行不能に 陥る直前まで提案手法の解と参照解は良く一致しており，最終状態での提案手法の解も充分な精度を持っている と期待できる .

\section{5 一軸圧縮解析}

解析領域は $0.5 \mathrm{~m} \times 1 \mathrm{~m}$ の矩形領域とし，左辺を左右拘束，下辺を上下拘束し，上辺を左右拘束と同時に下方向に $0.5 \mathrm{~m}$ 強制变位させる.節点数が 250 , 初期化用セル数が 438 ，応力点数が 2,439 であり，図 14 の通り解析領域に 均等に配置した。解析に用いた弾性物性値は， $\lambda=16.4429 \mathrm{GPa}$ および $\mu=0.335570 \mathrm{GPa}$ (ヤング率 $1 \mathrm{GPa}$ ，ポアソ ン比 0.49 に相当 ) である.強制变位がゼロから線形的に増加するとした仮想的な時間発展を行い, 自動時間増分 により時間発展は不均一な約 300 ステップに分割した .ABAQUS/Standardで図 14 の初期化用セルと同一の 3 節点 三角形 1 次要素分割を用い, 自動時間増分による適当な時間発展を行って得られた解 (参照解) も別途用意した。 $0.3 \mathrm{~m}$ 強制変位させた時点での提案手法の变形図 , および Mises 応力分布を図 15 左側に示す . 同じく $0.3 \mathrm{~m}$ 強制 変位させた時点での参照解の変形図, および Mises 応力分布を図 15 右側に示す. 変形図は互いに良く一致してお り，Mises 応力分布も変形が集中する右上角部を除いて良く一致している．

$0.5 \mathrm{~m}$ 強制変位させた最終状態での提案手法の変形図，および Mises 応力分布を図 16 に示す.参照解は強制変位 が $0.3 \mathrm{~m}$ を少し越えた時点で計算が続行不能に陥った為，提案手法の結果のみ示している.メッシュを用いる手法 では解が得られない大変形解析に対し，提案手法で妥当な変形状態および応力状態が得られていることが分かる． 仮想的な時間発展中の図中右下角の節点における水平变位の時刻歴を图 17 に示す.この解析例でも参照解の計 算が続行不能に陥る直前まで提案手法の解と参照解は良く一致しており，最終状態での提案手法の解も充分な精 度を持っていると期待できる。

\section{6 半面押込解析}

解析領域は $1 \mathrm{~m} \times 1 \mathrm{~m}$ の矩形領域とし，左辺を左右拘束，下辺を上下拘束し，上辺左半分を左右拘束と同時に下方 向に $0.5 \mathrm{~m}$ 強制変位させる.節点数が 500 , 初期化用セル数が 918 , 応力点数が 5,089 であり，図 18 の通り解析領 域に均等に配置した。解析に用いた弾性物性値は， $\lambda=16.4429 \mathrm{GPa}$ および $\mu=0.335570 \mathrm{GPa}$ (ヤング率 $1 \mathrm{GPa}$ ，ポ アソン比 0.49 に相当 ) である. 強制変位がゼロから線形的に増加するとした仮想的な時間発展を行い, 自動時間 増分により時間発展は不均一な約 500 ステップに分割した .

最終状態の変形図，および Mises 応力分布を図 19 に示す. 初期状態で上辺の中点の下方に位置していた節点は， 変形に伴ってまず左側に押し出され，光の後上辺中点よりも上方に移動している. 本例題はメッシュ固定の有限 要素解析では変形の早い段階で解析不能に陥る典型的な問題であるが, 妥当な変形状態および応力状態が得られ ていることが分かる. 


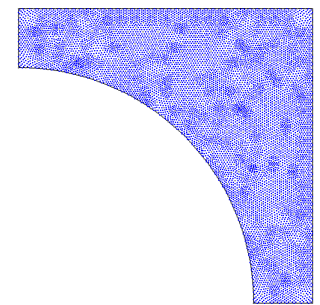

Fig. 10 Initial locations of nodes (gray dots) and stress-points (blue dots) for the uniaxial tension example.

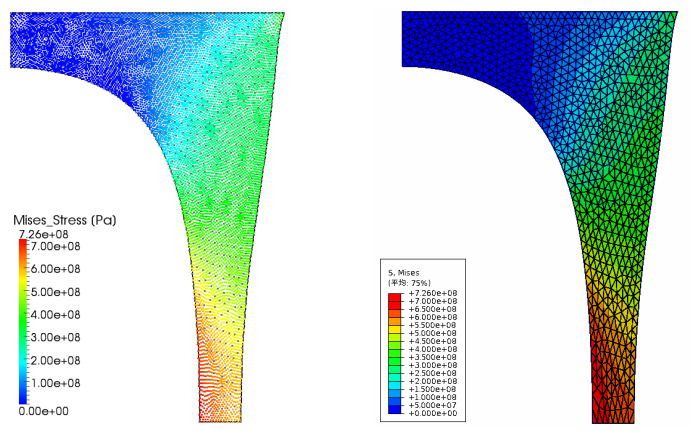

Fig. 11 Deformed shape and Mises stress distribution in the halfway state of the uniaxial tension example with the proposing method (on the left) and ABAQUS/Standard (on the right).

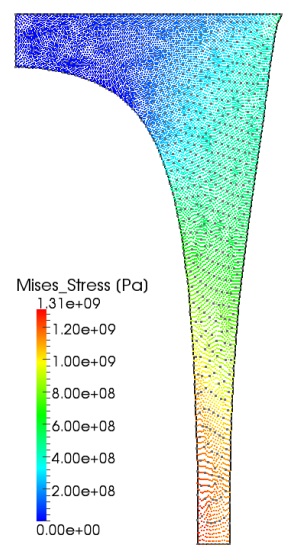

Fig. 12 Deformed shape and Mises stress distribution in the final state of the uniaxial tension example with the proposing method.

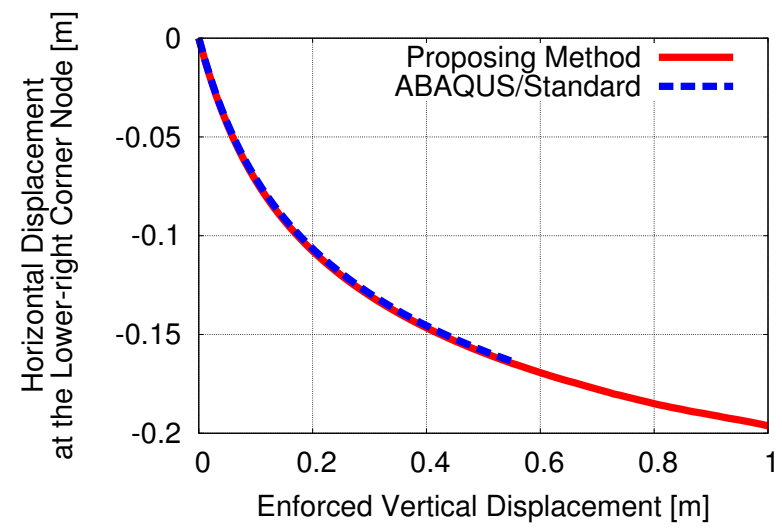

Fig. 13 Comparison of horizontal displacement at the lower-right corner node of the uniaxial tension example between the proposing method and ABAQUS/Standard. 


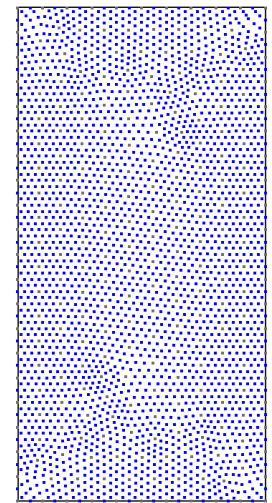

Fig. 14 Initial locations of nodes (gray dots) and stress-points (blue dots) for the uniaxial compression example.
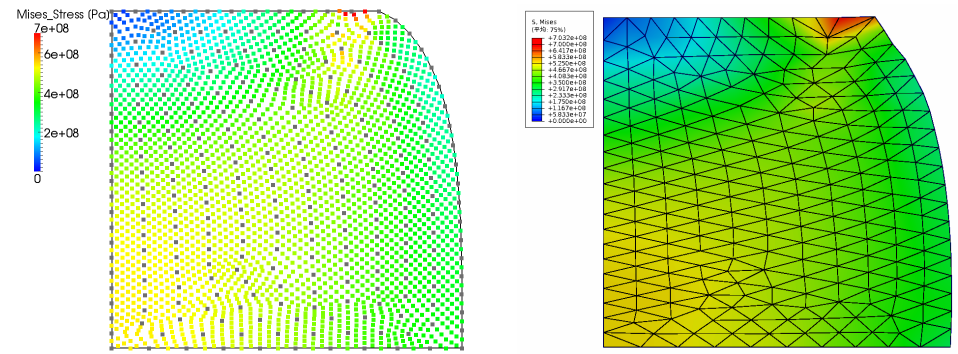

Fig. 15 Deformed shape and Mises stress distribution in the halfway state of the uniaxial compression example with the proposing method (on the left) and ABAQUS/Standard (on the right).

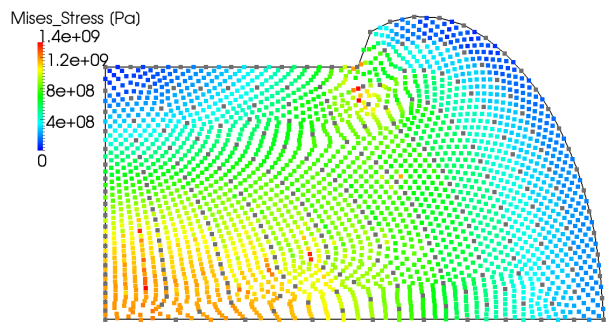

Fig. 16 Deformed shape and Mises stress distribution in the final state of the uniaxial compression example with the proposing method.

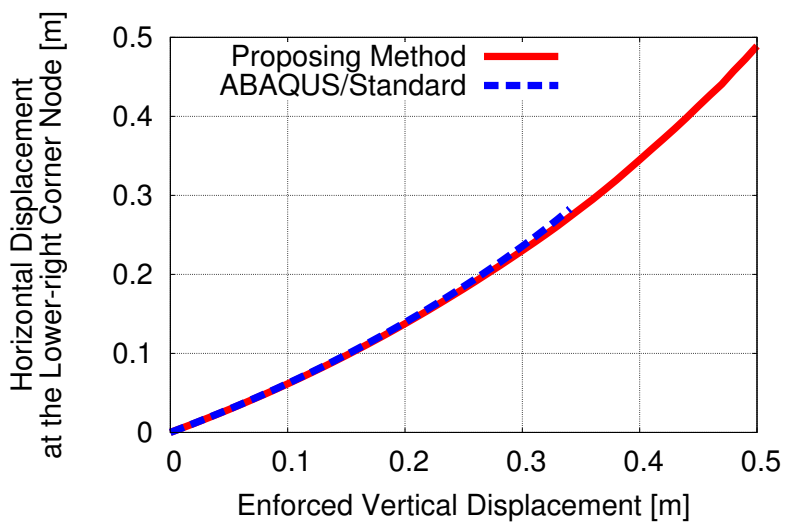

Fig. 17 Comparison of horizontal displacement at the lower-right corner node of the uniaxial compression example between the proposing method and ABAQUS/Standard. 


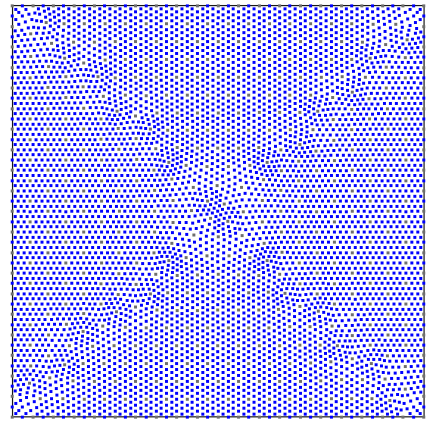

Fig. 18 Initial locations of nodes (gray dots) and stress-points (blue dots) for the half-side press example.

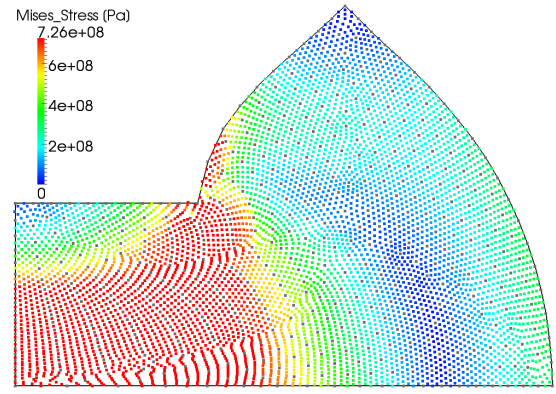

Fig. 19 Deformed shape and Mises stress distribution in the final state of the half-side press example with the proposing method.

5. 結言

浮動応力点積分によるメッシュフリー大変形解析手法を改良し，光の定式化を示した . 釣合方程式を内力増分 を用いた形式で記述することにより，従来の定式化で用いられていた仮想外力を廃し，内力の時間的連続性を保 つと同時に時間積分誤差を小さく抑えた . divergence-free 条件を満たす為の積分補正法 , および準陰的時間発展ス キームは従来通り定式化に取り入れ，パッチテストの通過性と Newton-Raphson ループの収束性を確保した .

パッチテストを含む種々の大変形解析例を示し , 解析解またはABAQUS/Standard による有限要素解との比較に よる定量評価を行った . 有限要素法が収束する変形範囲での提案手法の解は有限要素解と概ね一致しており，提案 手法が種々の大変形解析に対して実用に足る解析精度を持つことを示した . またメッシュ固定の有限要素法では 解を得ることが困難な大変形解析に対して, 提案手法で妥当な変形形状および応力分布を持つ解が得られること も示した .

本稿では 2 次元問題に対する定式化のみ記載したが，本定式化は 3 次元問題に対して容易に拡張が可能である . 提案手法の 3 次元化, 内力増分ベクトルを用いた釣合方程式の数学的に厳密な導出 , アダプティブ FEMの解析例 との比較，および接触解析の実現等は今後の課題としたい .

文献

(1) Belytschko, T., Lu, Y.Y., and Gu, L., "Element-free Galerkin methods", International Journal for Numerical Methods in Engineering, Vol. 37 (1994), pp. 229-256

(2) Li, S., and Liu, W.K., "Meshfree and particle methods and their applications", Applied Mechanics Reviews, Vol. 55, No. 1 (2002), pp. 1-34

(3) Nguyen, V.P., Rabczuk, T., Bordas, S., and Duflot, M., "Meshless methods: A review and computer implementation aspects", Mathematics and Computers in Simulation, Vol. 79, Issue 3 (2008), pp. 763-813

(4) Beissel, S., and Belytschko, T., "Nodal integration of the element-free Galerkin method", Computer Methods in Applied Mechanics and Engineering, Vol. 139 (1996), pp. 49-74

(5) Chen, J.S., Wu, C.T., Yoon, S., and You, Y., "A stabilized conforming nodal integration for Galerkin mesh-free methods", International Journal for Numerical Methods in Engineering, Vol. 50 (2001), pp. 435-466

(6) Chen, J.S., Yoon, S., and Wu, C.T., "Non-linear version of stabilized conforming nodal integration for Galerkin mesh-free methods", International Journal for Numerical Methods in Engineering, Vol. 53 (2002), pp. 2587-2615 
(7) Sze, K.Y., Chen, J.S., Sheng, N., and Liu, X.H., "Stabilized conforming nodal integration: exactness and variational justification", Finite Elements in Analysis and Design, Vol. 41 (2004), pp. 147-171

(8) Puso, M.A., Chen, J.S., Zywicz, E., and Elmer, W., "Meshfree and finite element nodal integration methods", International Journal for Numerical Methods in Engineering, Vol. 74 (2008), pp. 416-446

(9) Li, G. and Belytschko, T., "Element-free Galerkin method for contact problems in metal forming analysis", Engineering Computations, Vol. 18, No. 1/2 (2001), pp. 62-78

(10) Duan, Q. and Belytschko, T., "Gradient and dilatational stabilizations for stress-point integration in the element-free Galerkin method", International Journal for Numerical Methods in Engineering, Vol. 77 (2009), pp. 776-798

(11) Randles, P.W. and Libersky, L.D., "Normalized SPH with stress points", International Journal for Numerical Methods in Engineering, Vol. 48 (2000), pp. 1445-1462

(12) Rossi, R., Alves, M.K., and Al-Qureshi, H.A., "An element-free Galerkin method for metal forming simulations", Engineering Computations, Vol. 26, No. 4 (2009), pp. 327-346

(13) Onishi, Y. and Amaya, K., "A novel meshfree method for large deformation analysis of elastic and viscoelastic bodies without using background cells", Journal of Solid Mechanics and Materials Engineering, Vol. 4, No. 11 (2010), pp.1673-1686

(14) Krongauz, Y. and Belytschko, T., "Consistent pseudo-derivatives in meshless methods", Computer Methods in Applied Mechanics and Engineering, Vol. 146 (1997), pp. 371-386

(15) Jan, Y. and Sheu, T.W., "A quasi-implicit time advancing scheme for unsteady incompressible flow. Part I: Validation”, Computer Methods in Applied Mechanics and Engineering, Vol. 196 (2007), pp. 4755-4770

(16) Murea, C.M., "A semi-implicit algorithm based on the augmented Lagrangian method for fluid-structure interaction", Numerical Mathematics and Advanced Applications, Proceedings of ENUMATH 2007, (2008), pp. 555-562

(17) Zienkiewicz, O.C., The Finite Element Method for Solid and Structural Mechanics 6th Ed., (2005), Elsevier

(18) Liu, G.R., Meshfree Methods 2nd Ed., (2010), CRC Press

(19) SIMULIA Inc., "ABAQUS 6.8 Documentation, (2008), SIMULIA

(20) 久田俊明, 野口裕久, 非線形有限要素法の基礎と応用, (1995), 丸善 